\title{
Relation of Maturity to Some Fruit Characters of the West Indian Cherry'
}

\author{
Agripino Pérez López ${ }^{2}$
}

\section{INTRODUCTION}

The economic possibilities of the West Indian Cherry (Malpighia punicifolia L.) as a fruit crop for Puerto Rico have been emphasized because of its high ascorbic acid content $(1,3,5)^{3}$. Dry acerola-juice powder with a very high ascorbic acid content is being manufactured in Puerto Rico already. Asenjo (2) stated that this powder contains from 25,760 to 32,450 , and averages $27,220 \mathrm{mg}$. of ascorbic acid per $100 \mathrm{gm}$.

Because of its perishable nature, it is not believed that the acerola would have much value as a fresh market fruit except in very limited local markets. The ripe fruits cannot be handled satisfactorily, although the half-ripe fruit may be handled fairly well. During the harvesting season the fruits should be picked every other day, or at least every 3 days, as the ripe fruits tend to fall, and are very easily bruised and damaged. Fully-ripe crimsoncolored fruits, even though not bruised, will spoil very quickly. Actually the fruits are picked when they are beginning to turn a pinkish-orange or light-red color.

Because all the fruits never ripen on acerola trees at the same time, the tree must be visited by the fruitpicker five or six times during the harvesting season, making this operation very costly. Each time the ripe fruits are picked some damage is done to the tree, and the green-immature fruits are disturbed, inducing a premature fruit drop, causing a great reduction in yield.

It is necessary to establish a maturity index by which the grower can strip the fruits from the tree in order to reduce the number of harvests and the cost of picking. With this objective in mind such an experiment was established at the Isabela Agricultural Experiment Substation.

\section{PROCEDURE}

For this study a plot of about 1 acre of trees of West Indian cherries of the B-17 variety was subdivided in plots of $1 / 109$ acre to be harvested at different dates: May 3, May 7, May 10, May 14, May 17, and May 21.

1 Contribution from the Isabela Agricultural Experiment Substation.

${ }^{2}$ Assistant Agronomist, Agricultural Experiment Station, University of Puerto Rico, Rfo Piedras, P.R. The author wishes to express his sincere gratitude to Mr. A. Riera and Mr. J. Lebrón-Monclova of the Central Analytical Laboratory for analyzing the fruits for total solids and ascorbic acid.

Italic numbers in parentheses refer to Literature Cited, pp. 199-200. 
The picking dates were the treatments. Each treatment was randomized and replicated six times. Fruits of 12 trees were analyzed for each harvesting date. No data were taken on May 21 because, by that time, most of the fruits had dropped and insufficient were on the trees to be sampled. The laborers were instructed to strip all the fruits above $1 / 2$ inch in diameter, regardless of the degree of maturity.

The entire fruit production of each tree was weighed in the field and then taken to the laboratory where $2 \frac{1}{2}$ pounds per tree were taken and the percentage of ripe fruits determined. Each time that the word "ripe fruit" appears herein it refers to fruits that were either entirely red or turning yellow.

The rest of the fruits stripped from each tree were sent to the Main Station at Río Piedras for total-solids and ascorbic acid determinations. For

TABLE 1.-Record of climatological observations during the course of this experiment: May 1 to May 20,1962

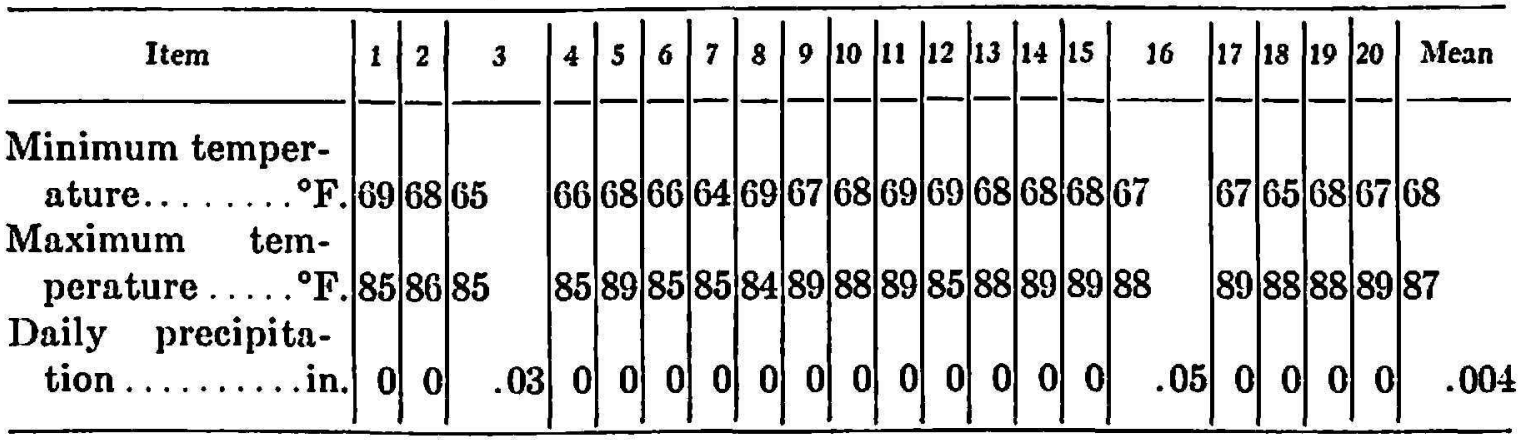

these analyses the entire fruit production ranging from $1 / 2$-inch diameter of fully-ripe fruits were ground in a Waring Blendor to make a composite sample of fruits of different degrees of maturity.

In all treatments the fruits were harvested early in the morning and analyzed during the first hours of the following morning. As shown in table 1, no rainfall or variations in temperature could be presumed to have induced variation on the ascorbic acid content of the fruits.

On each harvesting date the fruits that dropped from each tree were collected and weighed, regardless of treatments, but were disregarded in calculating the total vitamin $\mathrm{C}$ produced per tree.

\section{RESULTS AND DISCUSSION}

\section{PERCENTAGE OF RIPE FRUITS}

As can be seen in table 2 and figure 1 the percentage of ripe fruits obviously increased as the season progressed. It is interesting that, though many fruits were ripe on May 17, most of the total production had dropped. The percentages of ripe fruit harvested on May 14 and 17 were statistically 
larger at the 1-percent level of significance than those harvested on May 10, May 7, and May 3. On all other dates there were significantly more ripe fruits than on May 3. The differences between May 17, May 14, May 10 , and May 7 were not significant at the 5-percent level.

The standard error and least differences required for significance between mean percentages of ripe fruits are shown in the following tabulation:

\section{Ilem}

Least significant difference between highest and lowest means

Least significant difference between highest and 2nd lowest means

Least significant difference between highest and 3d lowest means

Least significant difference between 2 adjacents 5-percent level

20.14

18.81

17.01

14.01 1-percenl level

25.18

23.85

21.99

10.10

Standard error 4.75 with 20 d.f.

\section{TOTAL SOLIDS IN FRUITS}

The results in table 2 and figure 2 indicate that the total solids increased as the percentage of ripe fruits increased, or as the season progressed. This suggested that there might be a positive correlation between the percentage

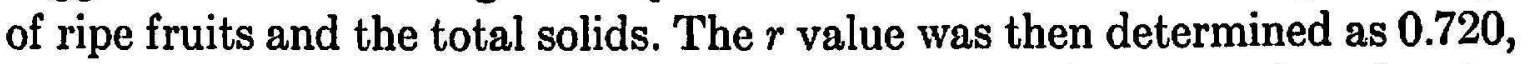
this being significant at the 1-percent level, table 3 . The proportion of variation in the total solids explained by the percentage of ripe fruits $\left(r^{2}\right)$ was 52 percent. This indicates that these two characters are well associated.

\section{PERCENTAGE OF ASCORBIC ACID IN FRUITS}

As shown in table 2 and figure 3 the ascorbic acid content of the acerola fruits decreased as the season progressed, or as the percentage of ripe fruits increased. In other words, when there are more ripe fruits on the acerola tree they contain less ascorbic acid or vitamin $\mathrm{C}$. This result is in accord with the findings by other workers (4) and (5) that the riper fruits contain less ascorbic acid than the greener ones.

The correlation coefficient of -0.780 obtained by correlating the values of the ascorbic acid percentages and the percentage of ripe acerola fruits is given in table 3 . This correlation was significant at the 1-percent level. It indicates that these two characters are very closely associated. The $\left(r^{2}\right)$ was determined as 61 percent, indicating the proportion of the variation in the ascorbic acid content which may be explained by the percentage of ripe fruits. 
TABLE 2.-The effect of the harvesting date on the percentage of ripe fruits, total solids, ascorbic acid, fruit picked, fruits dropped, and vitamin $C$ on acerola trees, May 8 to May 17, 1962

\begin{tabular}{l|c|c|c|c|c|c}
\hline & \multicolumn{7}{|c}{ Results for characteristics studied } \\
\cline { 2 - 7 } Harvesting dates & Ripe fruit & Total solids & Ascorbic acid & $\begin{array}{c}\text { Fruits } \\
\text { stripped } \\
\text { per tree }\end{array}$ & $\begin{array}{c}\text { Fruits } \\
\text { dropped } \\
\text { per tree }\end{array}$ & $\begin{array}{c}\text { Calculated } \\
\text { vitamin C } \\
\text { per tree }\end{array}$ \\
\hline & Percent & ${ }^{\circ}$ Brix & Percent & Posnds & Pounds & Posnds \\
May 3 & 58 & 6.90 & 1.72 & 4.82 & - & 0.08 \\
May 7 & 78 & 8.15 & 1.57 & 6.64 & 2.63 & .10 \\
May 10 & 79 & 8.17 & 1.58 & 3.80 & 1.39 & .06 \\
May 14 & 84 & 8.37 & 1.41 & 2.48 & 1.45 & .04 \\
May 17 & 92 & 9.15 & 1.46 & 1.25 & 1.43 & .02 \\
\hline \multicolumn{1}{c|}{ Mean } & 78 & 8.14 & 1.55 & 3.80 & 1.73 & 0.06 \\
\hline
\end{tabular}

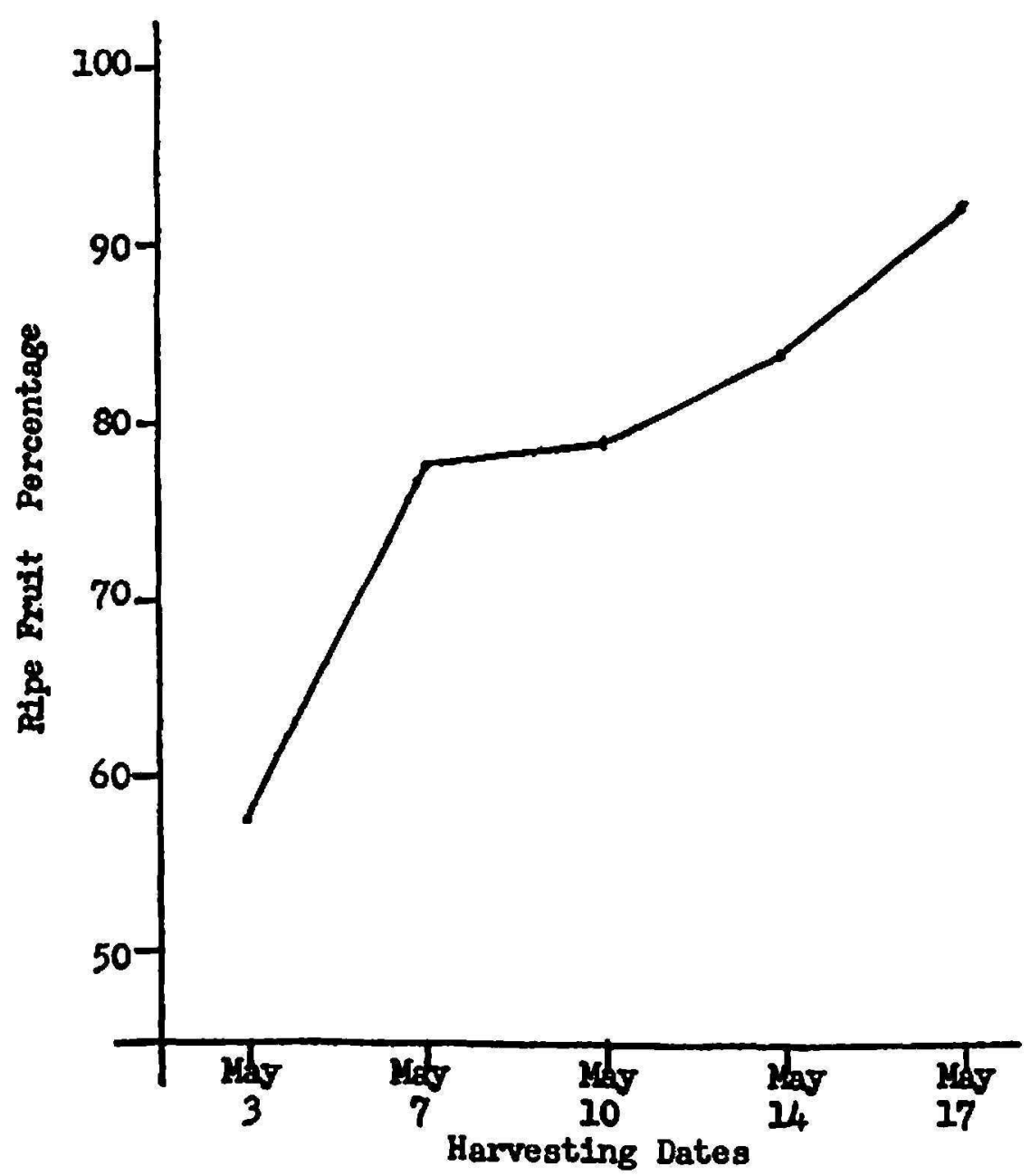

Fig. 1.-The effect of the harvesting date on the percentage of ripe fruits of the West Indian Cherry. 


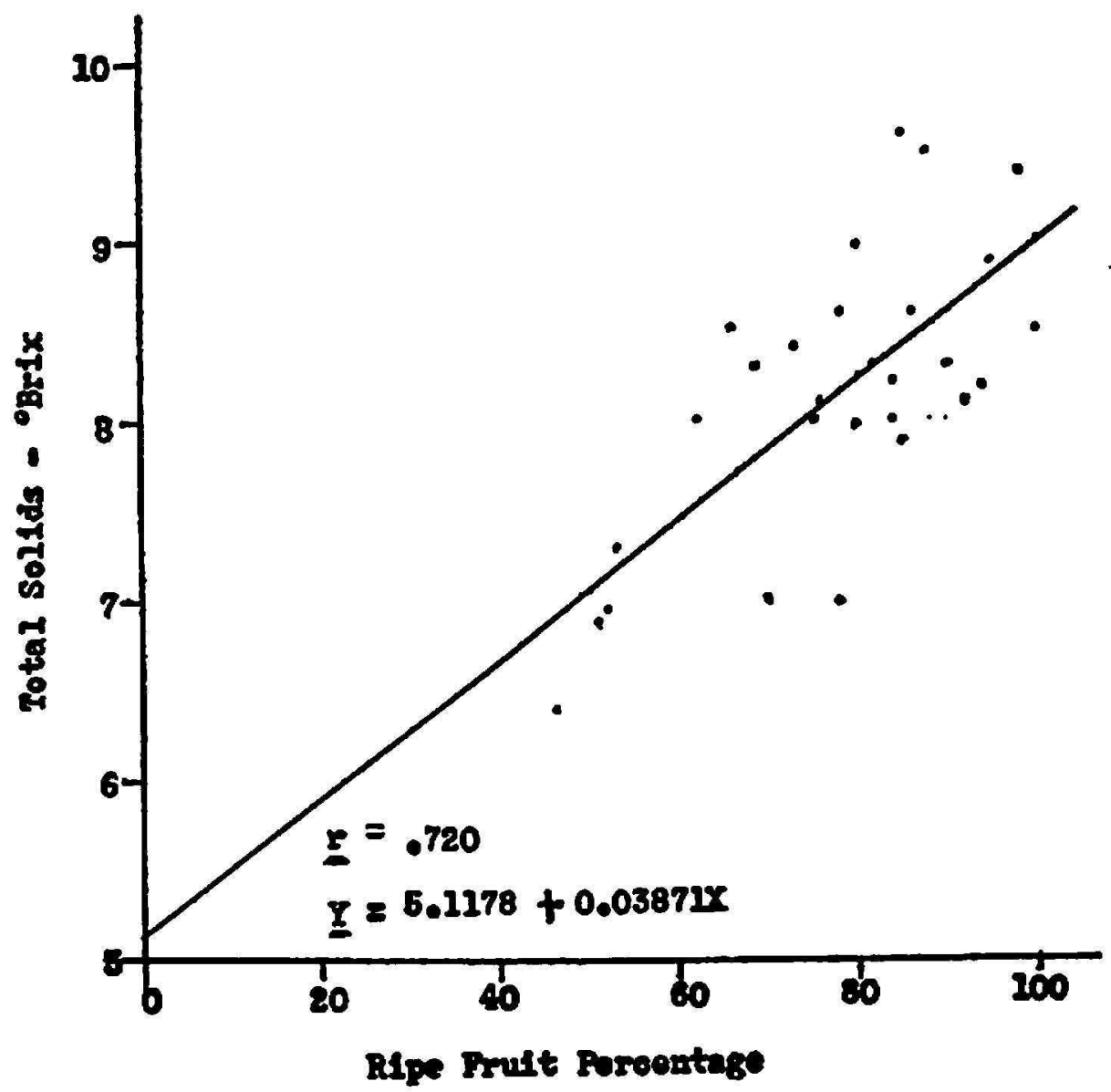

Fig. 2.-Relation between the percentage of ripe fruits and the total solids of the West Indian Cherry.

TABLE 3.-Correlation between percentage of ripe acerola fruits and characteristics studied in the May 1962 experiment

\begin{tabular}{|c|c|c|c|c|}
\hline \multirow{2}{*}{ Index } & \multirow{2}{*}{$\begin{array}{l}\text { Range of values } \\
\text { measured }\end{array}$} & \multicolumn{3}{|c|}{ Coefficient of correlation ${ }^{1}$ values } \\
\hline & & Experimental & $\begin{array}{l}\text { At 5-per- } \\
\text { cent level }\end{array}$ & $\begin{array}{l}\text { At 1-per- } \\
\text { cent level }\end{array}$ \\
\hline Total solids. & $6.4-9.6$ & $0.720 * *$ & 0.349 & 0.449 \\
\hline Ascorbic acid............ do. & $1.29-1.86$ & $-.780 * *$ & .349 & .449 \\
\hline Fruits stripped per tree......lb. & $0.15-24.30$ & .015 n.s. & .349 & .449 \\
\hline $\begin{array}{l}\text { Fruits dropped per tree...... do. } \\
\text { Ascorbic acid produced per acer- }\end{array}$ & $0.05-16.30$ & $.333 \mathrm{n.s.}$ & .388 & .496 \\
\hline 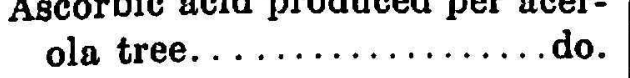 & $0.01-0.37$ & $.050 \mathrm{n.s.}$ & .349 & .449 \\
\hline
\end{tabular}

1 ** Significant at the 1-percent level; n.s. nonsignificant.

These findings suggest that, for the production of acerola juice with a high content of vitamin $\mathrm{C}$, it is better to strip the fruits from the acerola tree earlier in the season, instead of waiting to pick them when they are very ripe. 
The differences between the rest of the fruit characters studied were nonsignificant.

\section{SUMMARY}

An experiment was conducted on West Indian Cherries of the B-17 variety at the Isabela Agricultural Experiment Substation to study the re-

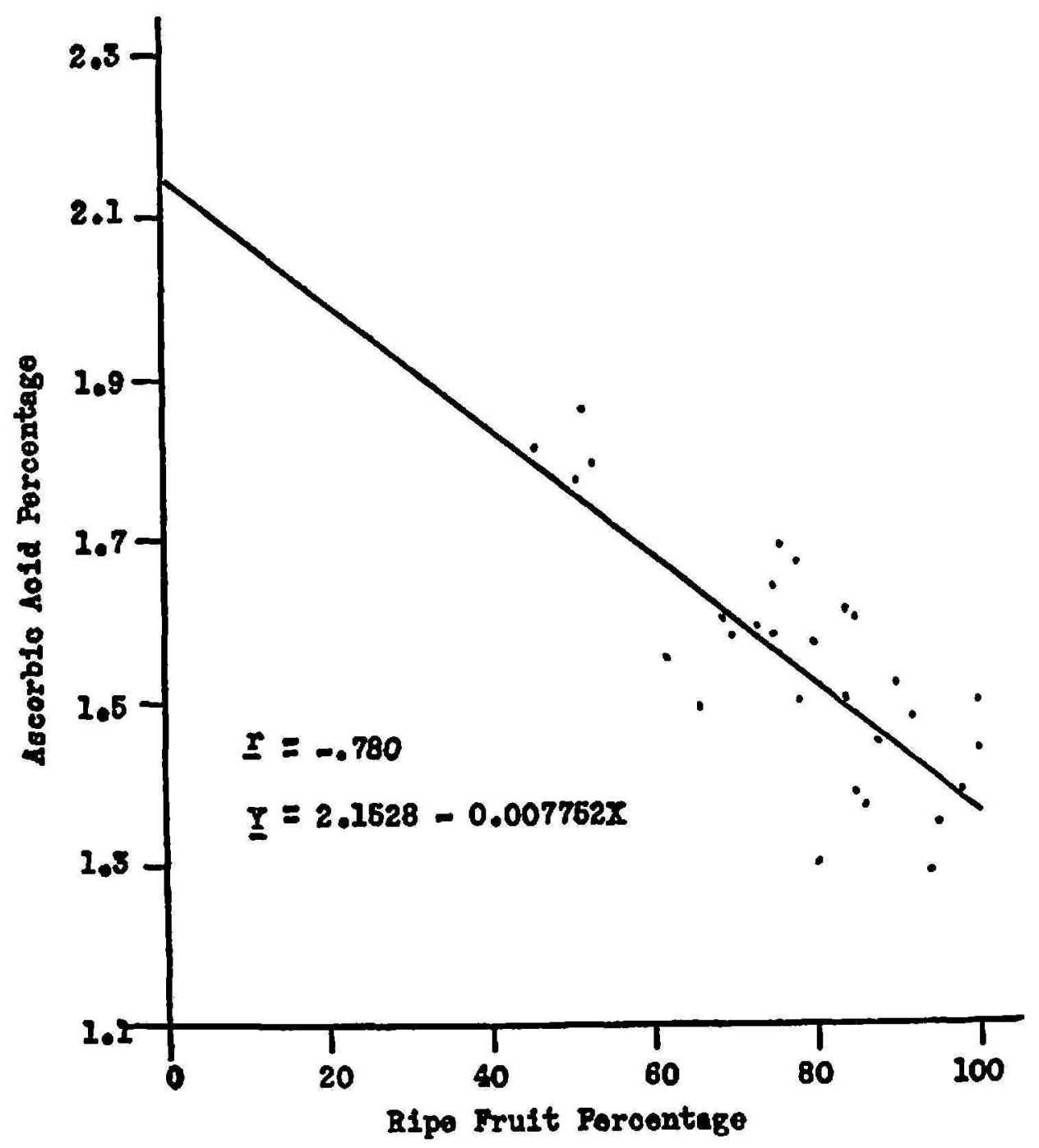

F1G. 3.-Relation between the percentage of ripe fruits and the ascorbic acid of the West Indian Cherry.

lationships between ripeness and chemical composition of the fruit at various harvesting dates.

Most of the trees bloomed practically at the same time, so that it was easy to replicate the harvesting dates: May 3, May 7, May 10, May 14, and May 17. The fruit characters studied in this experiment were: Percentage of ripe fruits, total solids, ascorbic acid, and fruit produced per tree. The major results of this experiment were as follows:

1. The percentage of ripe fruits increased as the season progressed. 
Eight percent of nonripe fruits were still found on the last harvesting date, May 17.

2. The total solids were much higher at the end of the season, indicating that the mature fruits had more total solids than the immature.

3. The ascorbic acid content was much lower at the end of the season, indicating that the percentage of this vitamin is reduced as the fruits mature.

4. The highly significant correlation coefficient between percentage of ripe fruits and total solids and ascorbic acid suggests that these characters are affected by ripeness.

\section{RESUMEN}

Se llevó a cabo un experimento en la Subestación Experimental Agrícola de Isabela con la variedad de acerola B 17 para estudiar las relaciones entre la madurez y la composición química de la fruta cosechada en distintas fechas.

Casi todos los árboles florecieron a la misma vez, facilitando así poder repetir las fechas de cosecha. Las cosechas se efectuaron en Mayo 3, Mayo 7, Mayo 10, Mayo 14 y Mayo 17, respectivamente. Los componentes de la fruta estudiados fueron los siguientes: Porcentaje de fruta madura en el árbol, sólidos totales, ácido ascórbico y frutas producidas por árbol.

Los resultados de este experimento fueron los siguientes:

1. El porcentaje de fruta madura comparado con el de fruta verde aumenta a medida que la época avanza. El 8 por ciento de la fruta aún sin madurar que se encontró en la última fecha de cosecha, mayo 17, indica que la fruta de acerola de un árbol no madura toda de una vez.

2. Los sólidos totales fueron mucho mayores al terminar la cosecha, indicando que la fruta madura tiene mucho más sólidos totales que la fruta sin madurar.

3. El contenido de ácido ascórbico fue mucho más bajo al final de la cosecha, indicando así que al progresar el estado de madurez de la fruta, se reduce proporcionalmente el contenido de vitamina $\mathrm{C}$.

4. Los coeficientes de correlación, altamente significativos para las correlaciones entre la madurez de la fruta con los sólidos totales y el ácido ascórbico, sugiere que la madurez afecta estos dos últimos caracteres.

\section{LITERATURE CITED}

1. Aróstegui, F., Asenjo, C. F., Muñiz, A. I., and Alemañy, L., Observations and data on a promising selection of the West Indian Cherry, Malpighia punicifolia L., J. Agr. Univ. P.R. 39 (3) 51-6, 1955.

2. Asenjo, C. F., Vitamin C in acerola and rose hips, J. Agr. Univ. P.R. 43 (3) 212-3, 1959.

3. Asenjo, C. F., and Freire de Guzmán, S. R., The high ascorbic acid content of the West Indian Cherry, Sci. 103 219, 1946. 
4. Hernández Medina, E., and Vélez Santiago, J., Response of the acerola (Malpighia punicifolia L.) to the application of lime and foliar sprays of magnesium and minor elements, Proc. Caribbean Reg. Amer. Soc. Hort. Sc. VIII Ann. Meeting 4 20-5, 1960.

5. Moscoso, C. G., West Indian Cherry-richest known source of natural vitamin C., Econ. Bot. 10 (3) 280-94, 1956. 